\title{
Sabat czarownic jako figura demonizująca noc*
}

The Sabbath of witches as a figure demonizing the night

Summary: The meeting of witches known as the "witches' Sabbath" is a semantic construct that denotes a set of imaginary ritual and magical actions. The female participants of these meetings - known as witches - were believed to free themselves from all the constraints of mundane mortal existence. Visions of the world losing its structure during a "devil's feast" on top of the "bald mountain" was bound to inspire fear, a reaction further intensified by the sense of a person losing one's bearings in the dark of the night. The night became a category perpetually combined with the figure of the witch for at least the following reasons: diminished self-confidence brought on by a person's wandering in the dark; lack of a set of rules that governed such meetings; uncritical belief in the reality of these meetings.

Keywords: teachings about culture and religion, folk beliefs, witch, Sabbath, night Słowa kluczowe: nauki o kulturze i religii, wierzenia ludowe, czarownica, sabat, noc

Postać czarownicy, choć współcześnie „odczarowana”, nieustannie powraca w związku z ożywioną debatą wokół czarownictwa toczącą się na wielu płaszczyznach ${ }^{1}$. Dyskusja dotyczy z jednej strony naukowej analizy

\footnotetext{
* Źródło finansowania badań przedstawionych w artykule: badania własne.

1 W literaturze przedmiotu występuje pojęcie czarownictwa tudzież czarostwa. Oba terminy traktowane są synonimicznie, mimo że czarostwo należy postrzegać jako archaiczną formę współczesnego czarownictwa. Określenia te odnoszą się do tzw. zbiorczej koncepcji magii (czarów), wypracowanej i spopularyzowanej przez pisma z zakresu teologii oraz demonologii. Na pojęcia te składa się kilka komponentów: szkodliwa magia (maleficium), nocne spotkania czarownic (sabaty), pakt z diabłem (z którego wynikają: naznaczenie czarownicy tajemniczym znamieniem oraz jej stosunki seksualne $\mathrm{z}$ demonami), profanacje hostii, ofiary z dzieci (często także kanibalizm) oraz rzekome metamorfozy czarownic (zob. m.in.: M. Pilaszek: Procesy o czary w Polsce w wiekach XV-XVIII. Kraków 2008, s. 47-66; K. Mikikulski, J. WijaczKa: Historia powszechna. Wiek XVI-XVIII. Warszawa 2012, s. 166-167; A. ZDZIECHIEWICZ: Staropolskie polowania na czarownice. Katowice 2004, s. 83-107; J. ADAмCZYк: Czary i magia w praktyce sąów kościelnych na ziemiach polskich w późnym średniowieczu. W: Karolińscy pokutnicy i polskie średniowieczne czarownice. Konfrontacja doktryny chrześcijańskiej z życiem społecznym czarownic. Red. M. KorCzewsKA. Warszawa 2007, s. 116-118). W artykule stosuję oba pojęcia zamiennie, zależnie od kontekstu wypowiedzi.
} 
zjawiska pod kątem metodologicznym ${ }^{2}$, z drugiej dociekań popularno-naukowych i komercyjnych przedsięwzięć popkulturowych ${ }^{3}$. Niezależnie jednak od formy podejścia wydaje się, że zjawisko to mocno nasiąknęło wizją ukształtowaną przez chrześcijańskich teologów i autorów pism demonologicznych, która $\mathrm{w}$ połączeniu $\mathrm{z}$ lokalnym folklorem (w tym również pozostałościami słowiańskich wierzeń dotyczących istnienia strzyg, wiedźm i jędz) stworzyła fundamenty dla swoiście pojmowanego mitu czarownicy ${ }^{4}$. Struktura owego mitu, mimo licznych miejscowych modyfikacji, opiera się na trwałym rdzeniu, w związku z czym niemal zawsze tworzyły ją te same komponenty. Jednym $\mathrm{z}$ istotniejszych takich elementów pozostawał zlot czarownic.

Wyimaginowane wizje sabatów stanowiły swego rodzaju pokłosie lęku przed nieznanym, w tym także przed ciemnością (niebezpieczeństwem czającym się w mroku). Próby racjonalizowania tych obaw

2 Omówienie wszystkich prac dotyczących analizowanej problematyki badawczej zajęłoby zbyt wiele miejsca, wspomnę tu jedynie o dwóch autorach, ukazując możliwie szeroki kontekst analityczny zagadnienia. Tematem tym zajmowali się przede wszystkim znawcy prawa - w tym Karol Koranyi. Jego artykuły zamieszczone w kwartalniku etnograficznym „Lud” sygnalizowały pewne problemy, będące też przedmiotem niniejszego artykułu (zob.: K. KoRANYI: Czary i gusła przed sądami kościelnymi w Polsce w XV i pierwszej połowie XVI wieku. „Lud” 1927, seria 2, t. 6 (26), z. 1-4, s. 1-25; IDEM: Lysa Góra. Studium $z$ dziejów ludowych w Polsce w XVII i XIII w. „Lud” 1928, seria 2, t. 7 (27), s. 57-74; IDEM: Beczka czarownic. „Lud” 1928, seria 2, t. 7 (27), s. 110-111). Stanisław Bylina rozpatrywał czary zawsze w odniesieniu do innych zjawisk kulturowych, szczególnie zaś zabobonów i reliktów pogańskich występujących w tradycyjnych społecznościach, głównie wiejskich (zob.: S. ByLInA: Kultura ludowa Polski i Słowiańszczyzny średniowiecznej. Warszawa 1999; Idem: Kościót a kultura ludowa w Polsce późnego średniowiecza. W: Literatura i kultura późnego średniowiecza w Polsce. Red. T. Micha£ówski, Warszawa 1993, s. 197-215; Idem: Magia, czary i kultura ludowa w Polsce XV i XVI w. „Odrodzenie i Reformacja w Polsce” 1990, t. 35, s. 39-52).

3 Bogactwo semantyczne wyobrażenia czarownicy sprawiło, że ta współcześnie stała się bohaterką określonych gatunków literatury, a także filmu. Lęk, jaki budziły czarownice, stał się inspiracją do stworzenia podgatunku filmów fantastyczno-przygodowych. Wskazuje na to sukces serii Blair Witch Project czy Gry o tron. Propozycją utrzymaną w konwencji stricte baśniowej są na przykład filmy: Czarownica (2014) i jego kontynuacja Czarownica 2 (2019), Nieustraszeni bracia Grimm (2015) czy Łowca czarownic (2015). Nie ma zatem wątpliwości, że świat czarownic jest wciąż popularnym elementem kultury masowej. Więcej na temat współczesnych obrazów czarownicy m.in. w opracowaniu: A. FiŁonowicz: Jak się pozbyć sekutnicy? O łowach czarownic w amerykańskich filmach fantastyczno-przygodowych. W: Czarownice. Studia $z$ kulturowej historii fenome$n u$. Red. A. Anczyk, J. Doroszewska, K.M. Hess. Katowice 2017, s. 183-192.

4 Spore znacznie dla kształtowania się tzw. mitu czarownicy miały lokalne wierzenia ludowe. Jego formowanie się i krystalizacja były konsekwencją wypracowania wspomnianej koncepcji czarostwa (szerzej pisałam na ten temat w artykule M. ТовоŁA-Feliks: Co czarownica $w$ kotle warzyła? Od magii i rytuału do praktyk leczniczych wiejskich zielarek. W: Doświadczenie choroby w perspektywie badań interdyscyplinarnych. T. 6: Ciało, choroby i świadomość społeczna - społeczne i metafizyczne aspekty profilaktyki $i$ terapii. Red. B. PŁonka-Syroka, M. DĄSAl. Warszawa 2020, s. 85-104). 
zmierzały zwykle do poszukiwania źródeł strachu; wydaje się, że wiarę $\mathrm{w}$ potajemne spotkania czarownic z diabłem tłumaczyć mógł w wielu aspektach ów lęk przed nocą. Celem w artykule jest zatem syntetyczny przegląd dostępnych w literaturze przedmiotu opisów odnoszących się do nocnych schadzek czarownic na „łysych górach” oraz wskazanie następstw, jakie niosło w strukturze wierzeń ludowych rozpowszechnienie tego rodzaju wyobrażeń ${ }^{5}$. Wierzenia dotyczące czarownic, mimo zmian środowiskowych, egzystencjalnych oraz światopoglądowych, stanowily integralny element wiejskiego mikrokosmosu (wiara w ich istnienie sięgała korzeniami mitów kosmologicznych), stabilnego, choć podlegającego pewnym zmianom wskutek obcych wpływów ${ }^{6}$. W wielu przypadkach wierzenia te przez długi czas nie były kwestionowane, traktowano je na równi z rzeczywistością. Dlatego też analiza sposobu myślenia (poświęcona mentalności mieszkańców wsi minionych wieków) nie pozwala nam wskazać wyraźnych granic pomiędzy wyobrażeniami dotyczącymi istnienia czarownic a ówczesnym światem realnym widzianym $\mathrm{z}$ perspektywy tych właśnie ludzi. Odtworzenie percepcji określonych atrybutów kultury może odbyć się jedynie $\mathrm{w}$ formie szczątkowej. $\mathrm{W}$ tym kontekście warto jednak odnieść się do formuły zaproponowanej przez Pawła Rutkowskiego ${ }^{7}$ - określanej mianem badania kultury mentalności - struktura ta $\mathrm{w}$ określonym stopniu pozwala na diagnozę korelacji fantazmatu z rzeczywistością.

\section{Zło czai się w mroku}

Wiara w moc i nadzwyczajne umiejętności czarownic przez długi czas utrzymywała szerokie rzesze ludności w lęku przed siłami nadprzyrodzonymi. Paradoksalnie też właśnie ona pomagała człowiekowi racjonalizować obawy dotyczące rzeczy, dla których nie potrafił znaleźć innego uzasadnienia niż ingerencja demona. Kluczowy był tu strach przed mro-

$5 \mathrm{Z}$ racji obecnie trudnej dostępności do źródeł rękopiśmiennych (pandemia COVID-19) skupiłam się wyłącznie na omówieniu prac opublikowanych. Utrudnia to nieco kompleksową analizę omawianego zjawiska, a także narzuca ramy czasowe i terytorialne artykułu. Podkreślę jednak, że dotarcie do oryginalnych źródeł mogłoby nieznacznie wpłynąć na rozszerzenie dotychczasowego stanu badań (ponowiono by jedynie analizę źródeł uprzednio przebadanych). Zachowane zapiski sądowe są rejestrem tylko pewnych aspektów całości zjawiska, gdyż autorzy takich dokumentów (urzędnicy) zazwyczaj streszczali wydarzenia rozstrzygające się na sali sadowej z użyciem w tym celu sformalizowanego języka prawniczego. Problem ten zauważa wielu badacz, wykorzystujących w swych analizach oryginalne dokumenty z procesów czarownic (por. np. J. AdAмсzyк: Czary i magia...).

6 Por. R. Tomicki: Religijność ludowa. W: Etnografia Polski. Przemiany kultury ludowej. T. 2. Red. M. Biernacka, M. Frankowska, W. Paprocka. Wrocław 1981, s. 29-70.

7 P. Rutкowski: Kot czarownicy. Kraków 2012, s. 28. 
kiem. Noc, będąca częścią cyklu dobowego, charakteryzuje się ciemnością niosącą $\mathrm{z}$ sobą dezorientację (w ciemności nieuchwytne są formy, kształty i postacie). Tym samym przełom dnia i nocy odzwierciedla dychotomiczny porządek świata, jest granicą, po której przekroczeniu stykamy się z metonimią chaosu. Jak zaznacza Piotr Kowalski, bezkształtność nocy na swój sposób wyraża także śmierć ${ }^{8}$. Ponadto ciemność oraz spowijająca ją cisza stwarzają egzystencjalne warunki do obcowania z sacrum, a także rodzą określone niebezpieczeństwo. Rozgrywa się wtedy pełne ambiwalentnych emocji misterium tremendum et fascinans (misterium grozy i urzeczenia). Zapadnięcie zmroku oznacza przeniesienie się w inną rzeczywistość, uosabiającą świat pełen imaginacji (czasem również halucynacji i zwidów). Jedną $\mathrm{z}$ wizji tego typu jest figura czarownicy niosąca z sobą liczne wyobrażenia, dotyczące między innymi sabatów. Już u Horacego znajdujemy zapis mówiący o tym, że: „[...] czarownice magicznymi zaklęciami nękają ludzkie umysły. Przy sobie mają zioła i zaklęte sznury, spowijają je ciemności nocy, a w zbieraniu kości i szkodliwych ziół patronuje im wędrowny księżyc (vaga luna)"9.

Fantazmatyczny obraz spotkań czarownic wprost utożsamiany jest tu z kategorią nocy ${ }^{10}$. Fantazmat rozumiem jako wytwór wyobrażeniowy oparty na podwalinach realnych wierzeń, a więc wzór będący pochodną różnorakich doświadczeń społecznych, traktowany na równi ze światem realnie istniejącym ${ }^{11}$ (determinowanym przez percepcję) ${ }^{12}$. Zakładam

8 Noc odwzorowuje wyobrażenie zaświatów, gdzie nie dokonuje się żadna komunikacja, gdzie nieprzydatne są kategorie, którymi posługuje się człowiek w swoim świecie. Zob. P. Kowalski: Noc [hasło]. W: Idem: Kultura magiczna. Omen, przesąd, znaczenie. Warszawa 2007, s. 351-355.

9 Horacy: Gawędy, I 8, 19-22, cyt. za: D. Budzanowska-Weglenda: Czarna magia antyczna i okrutne czarownice w Epodzie V Horacego. W: Czary, alchemia, opetanie w kulturze na przestrzeni dziejów. Studia przypadków. Red. J. Pietrzak-ThÉbaut, Ł. CүвULSKI. Warszawa 2015, s. 88.

10 Personifikacje nocy są zwykle dwojakie - ciemność wiązana jest $\mathrm{z}$ aktywnością czarów (strefą działalności czarownic i demonów) oraz pierwiastkiem żeńskim, również tym pasywnym, zogniskowanym wokół snu i marzeń sennych (odpoczynku i regeneracji). Oba te symbole wprost wpisują się w tematykę niniejszego opracowania. Por. J. TRESIDDER: Noc [hasło]. W: IDEM: Słownik symboli. Ilustrowany przewodnik po tradycyjnych wyobrażeniach obrazowych, znakach ikonicznych i emblematach. [Przeł. B. STокŁOsA]. Warszawa 1997, s. 139-141.

11 Por. M. Janion: Projekt krytyki fantazmatycznej. W: EAdEM: Prace wybrane. T. 3: Zło i fantazmaty. Kraków 2001, s. 157-184.

12 Niektórzy badacze dostrzegają $\mathrm{w}$ fantazmacie pewien sposób percepcji i definiowania rzeczywistości, regulacji działań, a w szczególności budowania tożsamości (zob.: A. Pankalla, M. Pietrzak, K. Gutкowska: Zastosowanie analizy konotacyjnej Ernesta Boescha do interpretacji obrazu Rafaela Santi "Adam i Ewa - grzech pierworodny”. „Studia Psychologica" 2014, nr 14 (1), s. 19, 21-22; E. BoEsch: The myth of lurking chaos. W: Between culture and biology: Perspectives on ontogenetic development. Eds. H. KeLLER, H. Portinga, A. Scholmerich. Cambridge 2002, s. 134. 
zatem, że jest on relacyjnie związany z rzeczywistością ${ }^{13}$. Dlatego będzie uosabiał nie tylko definicyjne ujęcie narracyjnego opisu pewnego sposobu myślenia, ale także wysublimowane odbicie prawideł psychologicznych wpływających na ludzkie zachowania - adekwatnych rzecz jasna do reguł kształtujących sposób myślenia (mentalność) społeczeństwa, w jakim funkcjonuje. Zarówno noc, jak i towarzyszące jej wizje owianych aurą tajemniczości zlotów czarownic stanowiły odzwierciedlenie złudnych projekcji ludzkiego umysłu. Stawały się one równocześnie istotnym komponentem wspomnianego już mitu czarownicy. Obie te figury (noc oraz czarownica) oscylowały między fantasmagorią nieznanego zagrożenia a niezrozumiałymi dla ówczesnego człowieka zjawiskami i wydarzeniami, konstrukty kulturowe demonizujące noc były zatem swego rodzaju odpowiedzią na budowanie marginesu społecznego, na którego płaszczyźnie funkcjonowały opowieści o biesiadnych spotkaniach wspólniczek diabła (wyjaśniające, dlaczego należy bać się nocy). Analogie tego typu były obecne $\mathrm{w}$ kulturze od dawna, wyrosły one $\mathrm{z}$ mitologii grecko-rzymskiej, w której bogini Hekate (córka nocy) ${ }^{14}$ utożsamiana była $\mathrm{z}$ boską patronką czarownic, także Kirke uchodziła w nowożytnej zbiorowej wyobraźni za archetyp czarownicy ${ }^{15}$. Procesom podobnej deformacji podlegały monomity Medei i hebrajskiej Lilith. Noc była jednak przede wszystkim szczególną towarzyszką Diany (w wielu analizach czarownictwo utożsamiane jest wprost $\mathrm{z}$ kultem dianicznym). W europejskiej przestrzeni kulturowej odzwierciedlało to nieprzerwaną konfrontację paradygmatu religijnego i laickiego. W rezultacie tej antynomicznej relacji mity pierwotne straciły swoje znaczenie, a czarownica stała się figurą nieodłącznie związaną $\mathrm{z}$ nocą ${ }^{16}$.

13 Por. J. KLIsZ: Nie-ludzka kondycja czarownic: związki z natura a zjawisko dehumanizacji. „Sensus Historiae” 2015, t. 21, nr 4, s. 91-112.

14 Argonautyki orfickie przedstawiają ją jako córkę Tartaru, greckie papirusy - jako dziecko Tartaru i Demeter. To w jej posiadaniu miały znajdować się pierwotnie klucze do Hadesu, dlatego też zapewne była uważana za strażniczkę świata mroku. Za: T. SANCHEZ: The temple of Hekate. Exploring the goddess Hekate through ritual, mediation and divination, London 2018, s. 18.

15 Zob. np. R. Graves: Mity greckie. Przeł. H. Krzeczkowski. Warszawa 1992, s. 111.

16 A. Chudzińska-Parkosadze: Problem monomitu jako źródła archetypu wiedźmy w kulturze europejskiej. W: Czarownice. Studia..., s. 69-78. 


\section{Diabelskie reduty ${ }^{17}$}

Około połowy XV stulecia nieznany z imienia inkwizytor sabaudzki stworzył traktat zatytułowany Errores Gazariorum seu illorum qui scobam vel bacalum equitare probantu, w którym przedstawił rozwiniętą koncepcję nocnych zlotów czarownic. Spotkania te postrzegane były jako kultowe zgromadzenia czarownic i czarowników pod przewodnictwem samego diabła. Powszechnie przyjęło się określać te zgromadzenia mianem sabatu, aby pejoratywnie odnieść się do święta zaczerpniętego z obrządku żydowskiego ${ }^{18}$. W rzeczywistości jednak źródłosłów tego terminu jest bliżej nieznany. Nie ma ono raczej wiele wspólnego z liczbą siedem ani też ze świętem judaistycznym ${ }^{19}$. Być może jest ono derywowane $\mathrm{z}$ francuskiego sébattre, co należy tłumaczyć jako "hałasować”, „bawić się" Wyjaśnienie to wydaje się przekonujące, gdyż odpowiadałoby atmosferze zabawy zgodnie z wierzeniami panującej podczas spotkań na „łysych górach". Mimo że w tekstach dotyczących czarostwa powszechnie używa się określenia „sabat”, w rodzimych protokołach dokumentujących zeznania w sprawach o czary jest ono niemal nieznane. Polskie domniemane czarownice udawały się raczej na biesiady, sejmy lub bankiety czartowskie ${ }^{21}$. Słowo „sabat” jest zapożyczeniem i upowszechniło się w Królestwie Polskim dopiero na przełomie XVII i XVIII wieku ${ }^{22}$. Nawet wtedy w miejscowych wierzeniach przebieg sabatu różnił się w wielu szczegółach od europejskiego pierwowzoru. Inną kwestią jest to, że niewątpliwie jeszcze w XVI stuleciu polskie społeczeństwo z rezerwą i z pewnym niedowierzaniem odnosiło się do wiary w czarostwo sabatowe ${ }^{23}$. Stanisław Ząb-

17 Reduta to rodzaj zabawy maskowej popularnej w XVIII wieku; „diabelskimi redutami” Jan Bohomolec nazwał spotkania czarownic; J. BономоLec: Diabeł w swej postaci z okazji pytania „Jeśli sq upiory” ukazany. Warszawa 1772, s. 139.

18 Por. R. Thurston: Polowania na czarownice. Dzieje prześladowań czarownic w Europie i Ameryce Północnej. Przeł. J. Kierul. Warszawa 2008, s. 12.

19 Szabas, sabat to w judaizmie siódmy, ostatni dzień tygodnia, będący według kalendarza żydowskiego dniem wypoczynku. Stanowi on czas świąteczny, upamiętniający cykl stworzenia świata oraz wyprowadzenie Izraelitów z Egiptu (por. Wj 20,9-11; Pwt 5,12-15). M. Bendowska, R. Żebrowski, Z. Borzymińska: Szabat [hasło]. W: Polski słownik judaistyczny. Delet, https://delet.jhi.pl/pl/psj?articleId=15847 [data dostępu: 2.12.2020].

20 Za: M.A. Murray: Wiedźmi kult w Europie Zachodniej. Studium antropologiczne. Przeł. A. Kisıel. Katowice 2016, s. 101. Mimo kontrowersyjności poglądów Margaret A. Murray wyjaśnienie to wydaje się dość adekwatne. Co istotne, Murray oparła swe tezy na założeniach wyartykułowanych wcześniej przez innych autorów, między innymi Jules’a Micheleta czy Charles'a Lelanda.

21 M. Pilaszek: Procesy o czary..., s. 349.

22 Świadomie posługuję się tym sformułowaniem, stosując go zamienne z rodzimymi odpowiednikami.

23 Umysły rodzimej ludności zaprzątały raczej myśli dotyczące możliwości rzucenia uroku na nich tudzież ich domostwo i zapewnienia zdrowia zwierząt hodowlanych. Aby 
kowic starał się tę "lukę" uzupełnić, przekładając Młot na czarownice, jednak w sądowych zeznaniach polskich czarownic wątki te były dość rzadkie $^{24}$. Dlatego też ówczesne sabaty w oczach sędziów stanowiły raczej kameralne zloty kilku czarownic. Już wtedy w zeznaniach pojawia się motyw paktu z diabłem, nie staje się on jednak wątkiem dominującym. Ważniejsze wydaje się samo wyobrażenie diabła, personifikowanego pod postacią rogatego kozła. Jego rogi symbolizowały władzę, jednocześnie stanowiły odwołanie do kultu księżyca, utożsamianego w niektórych mitologiach $\mathrm{z}$ bogiem - kreatorem świata ${ }^{25}$.

W światopoglądzie mieszkańców wsi polskiej szatańskie biesiady stały się miejscem dzikich tańców i dostatniego jedzenia. To wyobrażenie zdecydowanie górowało nad postrzeganiem sabatu jako skomplikowanych rytuałów oddawania czci diabłu (spopularyzowanych w zachodnioeuropejskich traktatach demonologicznych). Głównym punktem spotkań czarownic były zatem zwykle uczta i tańce, do których przygrywała orkiestra ${ }^{26}$. Pamiętajmy jednak, że taniec w czasach wczesnonowożytnych uchodził za coś zdrożnego. Wielokrotnie przestrzegano przed nim jako diabelskim narzędziem zepsucia. Ordynacje weselne wielu miast zabraniały wszelkich tanecznych nieprzyzwoitości. Zgodnie z wierzeniami, do tańca podczas sabatów przygrywali najczęściej mężczyźni, specjalnie sprowadzani w tym celu na „łysą górę”. Używali oni różnych instrumentów; najczęściej funkcję tę pełniły narzędzia rolnicze - radło bądź brona ${ }^{27}$.

Potrawy serwowane podczas sabatu mogły być wyszukane, ale najpowszechniejsze było wierzenie, że jadano tam różne paskudztwa (w tym nawet truchła dzieci składanych $\mathrm{w}$ ofierze, mięso wisielców oraz ropuchy - wszystko podawane bez dodatku soli). Przekonanie, że podczas tych uczt jadano jałowe, pozbawione smaku jedzenie, wynikało $\mathrm{z}$ postrzegania czarownictwa jako chrześcijaństwa „na opak” - istotne jest tu zwrócenie uwagi, że soli używano zwyczajowo w zabiegach antydemonicznych (egzorcyzmach) ${ }^{28}$. Abstrahując od tego, sabatowe menu pozwa-

dokonać maleficium, czarownica nie musiała uczestniczyć w diabelskich bankietach, te czyny wynikały wprost z jej złośliwej natury.

24 Wciąż aktualne są ustalenia karnisty Karola Koranyiego o tym, że poważny wpływ wierzeń zachodnich zaznacza się w Polsce dopiero u schyłku XVI stulecia (zob. K. Koranyi: Eysa Góra..., s. 57-74).

25 Por. R. Ho£DA: Czarownice a ugarycki kult boga z rogami. Popularne transformacje mitu. W: Czarownice. Studia..., s. 166-174.

26 Stereotyp ten całkowicie potwierdza mieszczący się w kanonie opis Benedykta Chmielowskiego (zob. B. Chmielowski: Nowe Ateny albo Akademia wszelkiej sciencyi pełna [...]. [Wybór i oprac. M. LipskA, J.J. Lipski]. Kraków 1966, s. 135).

27 J. Wijaczka: Polowanie na czarownice $i$ czarowników w Prusach Ksiązęcych w czasach wczesnonowożytnych. Toruń 2008, s. 196.

28 J. Delumeau: Reformy chrześcijańskie w XVI i XVII w. Katolicyzm między Lutrem a Wolterem. Przeł. P. KŁoczowski. Warszawa 2000, s. 86. 
la na ogół zorientować się, na czym w opinii sporej części społeczeństwa opierał się dobrobyt (choć jedzenie nie było zbyt wyszukane, to odwzorowywało fantazje kulinarne). Zgodnie $\mathrm{z}$ wierzeniami, w menu tym przeważały potrawy jarskie, spożywano kapustę, jarmuż, rzepę, kaszę, ser, placki, chleb. Karol Koranyi wspomina o cielęcinie, pieczonym drobiu, jagnięcinie, a także winie, małmazji, gorzale i kobylej urynie ${ }^{29}$. Jedzenie to zatem nie zawsze było smaczne, a podawane mięso miało mieć posmak gotowanego $\mathrm{psa}^{30}$. Na Pomorzu jadłospis wzbogacono o ryby, konkretnie - o ości. Pieczyste lub gotowane mięso zarezerwowane było zwykle dla czarownic wyższych rangą, co wynika z licznych podań. Serwowano im też wino i miody, w pozłocistych pucharach, gdyż nie kalały się one pospolitym piwem ${ }^{31}$. Dostępne opisy zazwyczaj odzwierciedlały stosunki społeczne panujące w danej epoce. Prezydujący sabatowi diabeł utożsamiał pana feudalnego, także wśród czarownic panowała określona hierarchia ${ }^{32}$. W XVI i XVII wieku obok feudalnej przysięgi wierności pojawił się nowy element - zaślubiny, które częściowo zastąpiły ów dawny pakt.

Wraz z nastaniem XVII wieku sabaty stawały się liczniejsze ${ }^{33}$. Zdaje się, że wyobrażenia ludowe nasyciły się już wówczas zdecydowanie bardziej obcymi wpływami, wzbogacając się również o obrazy orgii seksualnych. Nie można jednak i tego wątku zupełnie bagatelizować w odniesieniu do wcześniejszego okresu, bowiem to właśnie orgia w głównej mierze była wydarzeniem wprowadzającym chaos, grożący utratą dotychczasowej stabilizacji ${ }^{34}$, co w konsekwencji stanowiło doskonałe narzędzie manipulacji (sofistyki), kierowane głównie przeciw mieszkańcom wsi. Niezależnie jednak od tego fenomen sabatu związany był z mitologicznym sposobem kształtowania obrazu świata, co wskazuje na postrzeganie go jako ugruntowanej w świadomości cząstki świata realnego.

Podejście komparatystyczne odsyła nas do wierzeń pogańskich skompilowanych z późniejszymi naleciałościami założeń teologii chrześcijańskiej. W wierzeniach tych pozostawały pewne elementy rodzimego folkloru oraz lokalnych wierzeń ludowych przemieszane z obcymi nale-

29 K. Koranyi: Łysa Góra..., s. 68.

30 Z. ZdZIEChiewicz: Staropolskie polowania na czarownice..., s. 98.

31 M. Pilaszek: Procesy o czary..., s. 458.

32 Miejsce w sabatowej hierarchii zależało od stopnia opanowania magii. Przedstawiało się to rozmaicie w różnych regionach. W Świętokrzyskiem niektóre czarownice były w starszeństwie, ponieważ ich umiejętności wykraczały poza pospolite czarowanie bydła. W Kleszczewie czary na bydło rzucały bieglejsze w tej sztuce czarownice. Bardziej zaawansowane w sztukach magicznych umiały zaczarować wyszynk, a nawet szkodzić zdrowiu i życiu; starsze używały również czarów pogodowych.

33 M. Pilaszek: Procesy o czary..., s. 444-445.

34 M. Eliade: Kobieta, ziemia i płodność. W: Idem: Sacrum i profanum. O istocie religijności. Przeł. R. Reszke. Warszawa 1999, s. 119-121. 
ciałościami. W konsekwencji powstało zjawisko czarostwa (dziś określane częściej jako czarownictwo), a uwikłanym w nie kobietom niemal automatycznie można było przypisać wszelakie zło. W powszechnym mniemaniu to czarownice sprawiały, że świat został opanowany przez złowrogą tajemną asocjację. Na budowany w ten sposób obraz wpłynęła wypracowana już $\mathrm{w}$ średniowieczu i rozwinięta w okresie wczesnonowożytnym zbiorcza koncepcja czarów oparta na wierze w potajemne spotkania wyznawczyń szatana. Wierzono, że nowicjuszki podczas pierwszego pobytu na sabacie składały diabłu przysięgę wierności ${ }^{35}$. Spotkania te miały odbywać się w miejscach odludnych, najczęściej na „łysych górach”36, czyli różnego rodzaju wzniesieniach czy pagórkach, których nie brakowało w niemal każdej okolicy. Z czasem określeniem tym zaczęto nazywać wszystkie miejsca schadzek czarownic z czartami. Gołoborza i polany ułatwiały mitologizację miejsca, jednak w aktach procesowych odnajdujemy wzmianki o potajemnych spotkaniach: pod tzw. bożą męką, w lesie świerkowym, za borem, w borze, nad jeziorem, nad strugą, $\mathrm{w}$ błocie przy drodze, w polu, na łące, za wiatrakiem, koło bocianiego gniazda, za pańską stodołą, na grobach żydowskich, na cmentarzach katolickich, na miejscu straceń (pod szubienicą - obok rozstaju dróg to jedno $\mathrm{z}$ bardziej niebezpiecznych miejsc). Wierzono, że czarcie biesiady okazjonalnie były urządzane nawet $\mathrm{w}$ domu balwierza (cyrulika $)^{37}$. W ten sposób „łyse góry” stały się reprezentacją uniwersalnej symboliki środka świata $(\text { axis mundi) })^{38}$.

\section{Czarownice zmierzające na sabat ${ }^{39}$}

Zgodnie z wierzeniami, wielkie sabaty odbywały się raz, dwa razy do roku, choć ich częstotliwość zależała od lokalnej specyfiki zakorzenienia fantazmatu. Spotkania te kojarzono zazwyczaj z określonymi porami roku. W krajach słowiańskich największe zloty czarownic miały być urządzane w wigilię św. Jana (Kupalnockę), zaś na terenach niemiec-

35 J. WijaczKa: Magia i czary..., s. 192-194.

36 Przypuszcza się, że pojawiająca się w tradycji słowiańskiej Łysogóra związana mogła być z kultem Światowida. Według podań ludowych zlatują się w to miejsce czarownice na schadzki z diabłem. Zob. E.R. BuchHAmmer: Brocken [hasło]. W: IDEM: Mały leksykon przesąów. O czarnym kocie, trzynastce i wampirach. Krótki kurs zabobonu, magii i hermetyki. Pprzeł. M. STRuCzyńsKi. Warszawa 1994, s. 34.

37 K. Koranyi: Łysa Góra..., s. 57-74.

38 Zob. J. AdAmowski: Łysa Góra [hasło]. W: Stownik stereotypów i symboli ludowych. T. 1: Kosmos. Cz. 2: Ziemia, woda, podziemie. Red. J. Bartmiński, S. NiebrzegowSKA. Lublin 1999, s. 121-122.

39 Por. B. Podgórska, A. Podgórski: Encyklopedia demonów. Diably, diabetki, jędze, skrzaty, boginki... i wiele innych. Wrocław 2000, s. 22, 471. 
kich - w noc Walpurgii ${ }^{40}$. Za czas wzmożonej aktywności czarownic uznawano też między innymi dzień św. Łucji, wspomnienie św. Jakuba i Filipa, następnie św. Jerzego i św. Wojciecha oraz wigilie różnych świąt kościelnych, w tym zwłaszcza wigilia Bożego Narodzenia ${ }^{41}$. Istotne znaczenie przypisywano także takim dniom, jak: święto Zwiastowania Najświętszej Marii Panny, Wielki Piątek, Boże Ciało i Zielone Świątki ${ }^{42}$. W niektórych źródłach można znaleźć informacje o sabatach organizowanych $\mathrm{w}$ dni powszednie.

Czarownice miały się spotykać po nowiu oraz w czasie pełni księżyca. Wierzono, że ich zloty odbywały się w nocy ze środy na czwartek lub z piątku na sobotę. Mogły one przenosić się na miejsce spotkania realnie lub tylko we śnie ${ }^{43}$, obracając się na lewy bok. Lewa strona $\mathrm{w}$ symbolice była kojarzona $\mathrm{z}$ szatanem (odwołanie tego typu nasiliło się szczególnie pod wpływem średniowiecznej scholastyki). Widocznie zarysowuje się tu wątek oniryczny, gdyż sabat może się odbywać nie tylko $\mathrm{w}$ formie namacalnego spotkania, ale także $\mathrm{w}$ stanie snu (rzeczywistości astralnej). Przestrzeń astralna, będąca siedzibą bytów ponadzmysłowych (duchowych), w tym również demonicznych, zdaje się przyjmować uczestniczki diabelskich biesiad. Domniemane czarownice miały wprowadzać się w stan hipnotycznej ekstazy, smarując się różnego rodzaju specyfikami (najczęściej w postaci maści). Maść okazywała się pomocna także wtedy, gdy oblubienica szatana chciała fizycznie przenieść się na sabat. Podróż ta odbywała się następnie na różnych przedmiotach (te także należało pokryć stosownym specyfikiem). Najczęściej występującym $\mathrm{w}$ wierzeniach środkiem transportu był kij w różnych swych odmianach ${ }^{44}$. Czarownice latały więc na miot-

$40 \mathrm{~W}$ tym czasie dochodzi do nałożenia się na siebie dwóch świąt - pogańskiego święta uważanego w średniowieczu za „noc czarownic” i właściwego święta Walpurgi. Podczas obchodów nocy Walpurgi odbywały się tańce, odpusty, procesje, rozpalanie ognisk, głośne trzaskanie z biczów, bicie w dzwony, obchodzenie domów z pochodniami. Światło oraz dźwięk miały odpędzać czarownice.

41 J. AdAmowski: Czas i częstotliwość łysogórskich sabatów czarownic. „Annales Universitatis Mariae Curie-Skłodowska. Sectio FF: Philologiae” 1996-1997, t. 14-15, s. $399-409$.

42 B. Ogrodowska: Czarownica [hasło]. W: Eadem: Zwyczaje, obrzędy i tradycje w Polsce. Mały słownik. Warszawa 2001, s. 39-42; E. Szot-Radziszewska: Ludowy obraz czarownicy świętokrzyskiej w świadomości mieszkańców Kielecczyzny w świetle historycznych i współczesnych źródeł etnograficznych. W: Czary, alchemia, opętanie..., s. $291-303$.

43 Zdania na ten temat są jednak podzielone. Bohomolec w swym traktacie utrzymuje, że fizyczna obecność na sabacie była obowiązkowa: „[... [ kto nie stawił się na miejscy o wyznaczonej porze był dyscyplinowany karą pieniężną”. Nadmienia on także, że znamiona, których tak usilnie poszukiwano na ciałach oskarżonych o czary kobiet miały pełnić funkcję „,budzika” wzywającego na czarci bankiet. J. BономоLEc: Diabeł..., s. 133.

$44 \mathrm{Kij}$ oraz miotła jako środek transportu, za pomocą którego czarownice udawały się na sabat, tak mocno przylgnęły do wizerunku czarownicy, że z czasem demonolodzy 
łach ${ }^{45}$, ożogach, łopatach do chleba - stanowiących odwołania do symboliki kobiecej seksualności ${ }^{46}$. Do latania powszechnie służyły też żerdzie od płotu ${ }^{47}$, niecki, stępy, maselnice, ponadto przemieszano się na grzbietach kur i kogutów. W skrajnych przypadkach czarownice miały dosiadać w tym celu swoich osiodłanych mężów. Sporadycznie w różnych źródłach pojawiają się wzmianki dotyczące przemieszczania się na czarnym koniu lub czerwonej klaczy, czasem nietoperzu lub innym zwierzęciu. Wierzono, co warte podkreślenia, że były to nie prawdziwe zwierzęta, ale przemienione biesy i pomniejsze demony ${ }^{48}$. W Królestwie Polskim czarownice podróżowały niejednokrotnie na modłę szlachecką, w karecie lub bryczce, przy czym konie i powrozy dostarczali czarci, którzy przyjeżdżali po swoje towarzyszki. Czasem w zaprzęgu były obecne cztery czarne kozły lub wół. Niektóre czarownice pływały czółnem z kobylej głowy. Przemieszczały się cioty (jak czarownice nieraz nazywano w Wielkopolsce) na świni białej lub czarnej, na psie tudzież czarnym koźle, w którego przemieniony był diabeł. Rzadko udawały się na to spotkanie pieszo (piesze podróżowanie było domeną tych najbiedniejszych i najniższych rangą). Wizerunek czarownicy udającej się na sabat nie byłby pełny, gdyby nie domniemana jej umiejętność transgresji powłoki

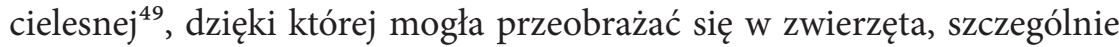
te, które na poziomie symbolicznym utożsamiano ze złem ${ }^{50}$. Oczywi-

utworzyli od słowa baculus (kij, laska) jedno z pogardliwych określeń czarownic, jakim jest bacularie. Zob. M. OzıembŁowsкi: Motyw lotu czarownic w tak zwanej zbiorczej koncepcji czarownictwa europejskiego. Świadectwa średniowieczne i wczesnonowożytne. „Almanach Historyczny” 2003, t. 5, s. 49-74.

45 Miotle przypisywano symbolikę magiczną o właściwościach katartycznych. Z magicznymi przymiotami miotły kojarzono gatunki drzew, z których zwykle wykonywano ten przedmiot, głównie były to brzozy, buki i jodły, symbolizujące życie, płodność i odradzającą się na wiosnę przyrodę. K. BRACHA: Średniowieczna metryka wizerunku świętokrzyskiej czarownicy. W: Czary, alchemia, opętanie..., s. 132.

46 Wedle dawnej symboliki wszystkie te przedmioty uważane były za atrybut kobiecej seksualności, jedynie widły (na których też rzekomo latano) lokowano w strefie męskości, z czasem jednak wszelkie przedmioty o podłużnym kształcie zaczęły być kojarzone z symbolicznym fallusem diabła. Por. E.R. Buchnammer: Miotła. W: Idem: Mały leksykon przesądów..., s. 107-108.

47 Zdaniem części badaczy latanie na żerdzi może mieć znacznie starszą metrykę od używania w tym celu kija czy miotły. Starogermańskie słowo hagazussa, będące najstarszą znaną formą niemieckiego określenia stosowanego w odniesieniu do czarownicy, oznacza starą kobietę latająca na żerdzi płotu. Żerdź z płotu, kojarzona w folklorze (szczególnie krajów niemieckich) z symboliką graniczną, stanowiła atrybut wykorzystywany w zabiegach magicznych. K. BRACHA: Średniowieczna metryka..., s. 119-136.

48 Z. ZdZiechiewicz: Staropolskie polowania na czarownice..., s. 93.

49 Por. J. Tuwim: Czary i czarty polskie oraz Wypisy czarnoksięskie. Warszawa 1924, s. 360.

50 Czarownice latały na czarnych kozłach, czarnych bocianach i wilkach - wszystkie te zwierzęta utożsamiane były z szatanem. Zob. E.R. BuchHAmmer: Miotła..., s. 107. 
ście również diabeł, zależnie od okolicy oraz miejscowych wierzeń, mógł przybrać różne postaci: czarnego psa, robaka, konia, sowy, nietoperza lub muchy; najczęściej jednak przeistaczał się w wspomnianego już kozła. Co ciekawe, w całej Europie Zachodniej świnia jako zwierzę była zupełnie wyłączona $\mathrm{z}$ wszelkich rytuałów czy ceremonii i nie występowała jako personifikacja postaci diabła ${ }^{51}$.

Wyobrażenie wylotu na sabat przez komin, opisanego w Złotej legendzie przez Jakuba de Voragine, spopularyzowane następnie przez ryciny Pietera Breughla Starszego ${ }^{52}$, stało się elementem ludowej wyobraźni. Komin, jako przestrzeń ciemna i stale otwarta, był typową dla wielu wierzeń drogą dostępną dla duchów i demonów. Przed wylotem przez komin czarownice miały smarować się „sprośnymi maściami”. Wcierały je pod pachami, na podeszwach stóp, czole, piersiach i krzyżu. Maści dostarczał w słoikach sam diabeł albo też czarownice robiły je samodzielnie, stosując się do jego instrukcji. Ingrediencje, $\mathrm{z}$ których je przygotowywano, zwykle nie były wskazywane ${ }^{53}$, stąd też wszelkie próby ustalenia takich receptur są w rzeczywistości błądzeniem wśród domysłów i przypuszczeń. Za sprawą wiary w magiczne właściwości owych maści przyjęło się, że czarownice udawały się na sabat, lecąc. Kwestia iluzoryczności i realności lotu sprawiała wiele problemów, doprowadzając czasem do absurdalnych racjonalizacji. Wierzenia te są niewątpliwie starsze niż chrześcijańska koncepcja czarów. Już w mitach grecko-rzymskich odnajdziemy demoniczne kobiety zbliżone do upiorów. Odbywały one nocne wędrówki w powietrzu, aby porywać dzieci i wysysać ich krew. Zwano je lamiami, strzygami lub empuzami. Nie zawsze zresztą były to postacie czyniące wyłącznie $z^{5}{ }^{54}$. Co jednak istotne, wątek ekstatycznej podróży w powietrzu nie stanowił elementu wizji czarownicy od początku jej istnienia. Jak wynika z licznych powołań na fragmenty nieistniejącego dziś karolińskiego kapitularza Canon Episcopi z około 906 roku $^{55}$, przez długi czas, wbrew wierzeniom „prostego ludu”, Kościół starał się przekonywać, że loty z użyciem

51 Służyć mogła jedynie za środek transportu dla czarownicy.

52 Por. np. Święty Jakub i mag Hermogenes.

53 M. Pilaszek: Procesy o czary..., s. 446-447.

$54 \mathrm{~W}$ średniowieczu istniał ludowy zwyczaj przygotowywania na noc w okresie Bożego Narodzenia tzw. stołu szczęścia z posiłkami dla demonów żeńskich. Wierzono, że odwiedzały one domy i przynosiły szczęście oraz pomyślność.

55 Tzw. Canon Episcopi to praca Regino z Prüm, napisana w Trewirze, Libri duo de synodalibus causis et ecclesiasticis disciplinis. Stwierdzono w niej, że powietrzne nocne loty kobiet w orszaku pogańskiej bogini Diany to iluzja, w którą nie należy wierzyć pod żadnym pozorem. Ów zbiór prawa przygotowany dla diecezji trewirskiej zdobył ponadregionalne znaczenie dzięki temu, że został umieszczony przez Brucharda z Wormacji (965-1025) w jego Decretum, a następnie przejęty przez Ivo z Chartes, od którego trafił z kolei do zbioru prawa kościelnego Corpus Iuris Canonici (kodeks ten obowiązywał do $1918 \mathrm{roku})$. 
różnych przedmiotów są jedynie wytworem fantazji ${ }^{56}$, a wiara $\mathrm{w}$ nie jest grzechem. Analogiczne stanowisko Kościoła wobec praktyk magicznych pokazuje także powstały na początku XI wieku zbiór kościelnych przepisów dyscyplinujących stworzony przez biskupa Burcharda w Wormacji. Czytamy w nim: „, [...] uwiedzione demonicznymi wizjami kobiety, wierzą i utrzymują, iż jeżdżą w nocy na pewnych zwierzętach razem z Dianą boginką pogańską; przemierzają tak w głębokim milczeniu w nocy duże odległości oraz są posłuszne rozkazom tej bogini. Tyczem to wszystko jest fałszem" "57. Jeszcze w XV wieku profesor teologii Uniwersytetu Paryskiego Wilhelm Adeline potwierdził w jednym z kazań, że sabat czarownic jest tworem wyobraźni ludzi naiwnych ${ }^{58}$. Były to już jednak coraz częściej głosy odosobnione. Autorzy traktatów teologicznych wykorzystali swe doświadczenie i szerokie oczytanie, aby dowieść, że czarownictwo widziane przez pryzmat ich wyobrażeń istnieje. Niejako na potwierdzenie swych słów starali się oni wykazać przede wszystkim ogrom czynionego przez czarownice zła (działania te określano jako maleficium). Opierając swe wywody na opowieściach ludowych o diabłach i czarownicach, raportach z dość licznych wówczas procesów o czary, konsekwentnie budowali oni obraz czarownicy mordującej i składającej w ofierze niechrzczone dzieci, szkodzącej zasiewom i plonom, wywołującej burze i gradobicia, sprowadzającej śmierć i choroby na ludzi oraz zwierzęta hodowlane, a w końcu latającej na sabaty ${ }^{59}$.

Zmiany w stosunku do wypowiedzi zawartych w Canon Episcopi argumentowano pojawieniem się nowego groźniejszego rodzaju czarownic, które faktycznie potrafiły latać (pokazuje to ewolucję samego mitu). Głosy podważające realność sabatów były wtedy sporadyczne ${ }^{60}$, choć

56 Niektórzy badacze przypuszczają, że średniowieczne wierzenia dotyczące lotów w powietrzu i pokonywaniu znacznych przestrzeni w błyskawicznym tempie są pozostałością pogańskich praktyk ekstatycznych, które były podobne do transu szamanów syberyjskich. E. Роткоwsкi: Czary i czarownice. Warszawa 1970, s. 289-291.

57 Cyt. za: ibidem, s. 99.

58 Oskarżony za to przez inkwizycję wyznał na torturach, że sam należy do sekty czarowników. Dzięki temu przyznaniu wprawdzie uniknął stosu, ale został skazany na dożywotnie więzienie. E. Роткоwsкi: Czary i czarownice..., s. 126.

59 Ibidem, s. 119-220.

$60 \mathrm{Na}$ początku XVI wieku franciszkanin Samuele de Cassinis wystąpił przeciw wierzeniom w nocne loty czarownic, a Gianfrancesco Ponzinibio usiłował wykazać, że powietrzne jazdy na różnych przedmiotach są jedynie złudzeniem. W połowie XVI stulecia w obronie czarownic wystąpił lekarz Johann Weyer. Procesy o czary krytykował też zdecydowanie szlachcic angielski Reginald Scot. W pierwszej połowie XVII wieku wystąpili w obronie czarownic dwaj duchowni niemieccy - Adam Tanner i Friedrich Spee. Pierwsze krytyczne głosy były wymierzone przede wszystkim w procedurę procesów. Nikt z owych oponentów wiodącej koncepcji czarostwa nie zaprzeczał jednak, że diabeł istnieje i działa. Diabeł był dla ówczesnych symbolem zła. Wypowiedzi Cassinisa i Ponzinibio nawiązujące stricte do nierealności sabatowych zgromadzeń są więc, mimo racjonalnych przesłanek, dość odosobnione. Za: E. Роткоwsкi: Czary i czarownice..., s. 126-127. 
na tyle słyszalne, że w końcu niektórzy poczęli zajmować stanowisko, zgodnie z którym uczestnictwo w nocnych biesiadach czarownic było mrzonką, ucieleśnieniem fantazji, złudzeniem podsycanym przez działanie narkotycznych substancji powodujących halucynacje lub wytworem wyobraźni powodowanym irracjonalnym lekiem przed czającym się w mroku zagrożeniem.

\section{Wnioski}

Niewątpliwie każda z części sabatu wymaga oddzielnego komentarza. Jeżeli kolektywny obraz czarownic nie tylko odpowiada aspektowi żeńskiego pierwiastka, ale także jest uosobieniem Wielkiej Bogini (znanej również jako Bogini Matka), to kozioł jest manifestacją elementu męskiego. Jego obraz nawiązuje do dionizyjskich bachanaliów, podczas których obficie lało się wino. $\mathrm{W}$ tym wypadku mamy do czynienia $\mathrm{z}$ atrybutem, jakim są rogi, utożsamiane z płodnością oraz symbolicznym wcieleniem męskich sił seksualnych ${ }^{61}$, a także kojarzone z siłami lunarnymi. Próbując dociec, w jaki sposób narodziła się koncepcja sabatu, możemy założyć niejako a priori, że jest ona niewątpliwie starsza od sądowych procesów o czary. Już bowiem heretyków w XIII stuleciu oskarżano o tajemne zebrania, którym przewodniczyć miał diabeł. To między innymi katarom zarzucano, że na nocnych zebraniach z ucztami i orgiami adorowali władcę piekieł. Zastanawiająca jest zbieżność dat głównych obrzędów sabatowych i dawnych świąt pogańskich. Wielkie czartowskie bankiety przypadały w okresie świąt ludowych wywodzących się z tradycji przedchrześcijańskich $^{62}$, były to uroczystości związane z rolnictwem i hodowlą. Jan Stanisław Bystroń, badając to zagadnienie, ustalił ponad wszelką wątpliwość, że już na długo przed przyjęciem przez Polskę chrztu obowiązywał na jej

61 M. Oesterreicher-Mollwo: Leksykon symboli. Przeł. J. Prokopiuk. Red. L. Robakiewicz. Warszawa 2009, s. 131.

62 Murray we wspomnianej pracy Wiedźmi kult... stwierdza, że od zamierzchłych czasów pogańskich aż po wiek XVII w Europie Zachodniej we wszystkich grupach społecznych (od plebsu do arystokracji i rodzin królewskich) był rozpowszechniony i skrupulatnie uprawiany kult rogatego boga płodności o dwóch twarzach. Przedstawiony rytuał do złudzenia przypominał ceremoniał sabatów opisywanych przez tzw. sprengerystów. Stanowisko reprezentowane przez Murray mieściło się również w paradygmacie antropologicznym, ponieważ sama Murray inspirowała się dziełami Jamesa G. Frazera. Współcześnie jednak jej hipoteza stanowi w znacznej mierze przedmiot krytyki. Środowisko akademickie zresztą od początku było wysoce sceptyczne wobec koncepcji Murray, wskazując nie tylko wadliwość zastosowanego aparatu badawczego, ale też fakt analizowania fenomenu czarownic niejako w oderwaniu od rzeczywistości kulturowej. Por.: J.B. Russell: Krótka historia czarownictwa. Przeł. J. Rybski. Wrocław 2003; B.P. Levack: Polowanie na czarownice w Europie wczesnonowożytnej. Przeł. E. Rutкowski. Kraków 2009. 
terenach rodzimy kalendarz obrzędowy, w którym ten typ świąt odgrywał znacząca rolę. Pory roku wyznaczały w owych czasach kilka typów świąt związanych z odpowiednimi praktykami (agrarnymi, wegetacyjnymi, płodnościowymi). Był to czas kojarzenia młodych par, a jego echem są do dziś zachowane zwyczaje świętojańskie lub zabawy przypadające na okres Zielonych Świątek. Interesującym dowodem, że takie obrzędy odbywały się na terenie Polski, jest statut biskupa Andrzeja Łaskarza, $\mathrm{z}$ pierwszej połowy XV wieku, zakazujący nocnych tańców $\mathrm{w}$ wigilię św. Jana oraz św. Piotra i Pawła z powodu dokonywanych wtedy wielu niemoralnych czynów: nierządu, cudzołóstwa, kazirodztwa. W tym samym mniej więcej czasie kaznodzieja Jan z Michorzyna gromił kobiety i dziewczęta, które w wigilię Zielonych Świątek zamiast iść do kościoła gromadziły się na tańcach ${ }^{63}$.

Przytoczone fakty pozwalają przypuszczać, że koncepcja sabatu zrodziła się $\mathrm{w}$ środowisku średniowiecznych teologów i inkwizytorów pod wpływem obserwacji tego rodzaju obrzędów ludowych, wynikających wprost $\mathrm{z}$ pozostałości kultów pogańskich. Utworzony raz schemat był stopniowo rozbudowywany i w określonym stopniu modyfikowany. $\mathrm{Na}$ podstawie zapisów obecnych w zachowanych protokołach sądowych można sądzić, że same czarownice niejednokrotnie były głęboko przekonane o swoim uczestnictwie w sabatach. Mogły one rzeczywiście brać udział w obrzędach ludowych na poły pogańskich, które sędziowie utożsamiali później właśnie z sabatami. Poza tym sporą rolę odegrały tu z pewnością wspomniane już halucynacje i sny. W celu zabezpieczenia się przed konsekwencjami uroków rzucanych przez czarownice zbierające się o północy na sabat, podczas wielu świąt trzaskano z bicza. Miało to znaczenie apotropeiczne - nikt nie znał przecież dokładnie lokalizacji „łysej góry”, na której odbywał się czarci sejm. Wrzucano więc "czartowskie zioła" do ognia, któremu przypisywano szczególne właściwości oczyszczające $^{64}$. Z tych samych powodów długo zachował się zwyczaj palenia podczas nocy sobótkowej wypchanej kukły przedstawiającej wiedźmę. Przy całym krytycyzmie, z jakim winniśmy podchodzić do prób identyfikowania dawnych wyobrażeń o sabacie ze świętojańskimi biesiadami, nie sposób odrzucić sugestii dotyczących erotycznego aspektu owych obrzędów. Z obecnych w źródłach opisów przebiegu tego rodzaju ceremoniału dowiadujemy się, że każdy z uczestników owych zgromadzeń brał udział w odurzającym tańcu. Silne podrzucanie głowy, jednostajna rytmika i zaklęcia, wreszcie towarzystwo wielu podobnie zachowujących się postaci - w konsekwencji takich zachowań u osób biorących w nich udział mogło się pojawić przekonanie, że były one uczestnikami sabatów, co powtarzały potem $\mathrm{w}$ trakcie przesłuchan sądowych. W tym miejscu

63 E. Роткоwski: Czary i czarownice..., s. 226-228.

64 J. SAMP: Droga na sabat. Gdańsk 1981, s. 8. 
wyczerpują się nasze możliwości w zakresie rekonstruowania dawnych struktur myślowych ${ }^{65}$.

Reasumując, możemy jednak przyjąć, że figura czarownicy lokowana była $\mathrm{w}$ fantazmatycznej przestrzeni tego, co pierwotnie nieokiełznane przez normy kulturowe, a zatem społecznie groźne. Choć część wątków obecnych $\mathrm{w}$ zbiorowym wyobrażeniu o sabatach stanowiła import topicznej symboliki zgodnej ze staroeuropejską warstwą wierzeniową, opartą na fundamencie wierzeń chtoniczno-wegetacyjnych, w większości dobrze wpasowywała się w polskie realia. Wątek orgiastycznych sabatów funkcjonował $\mathrm{w}$ fantazmatycznych wyobrażeniach, skutecznie demonizując noc, ukazując jednocześnie skomplikowany obraz relacji człowieka $\mathrm{z}$ mrokiem. Noc jest pochodną skrywanej w mroku tajemnicy, a jednocześnie przestrzenią, w której rodzi się fantazmat kreowany przez ową tajemnicę. Konstrukt nocy rozważanej przez pryzmat zagrożenia, jakie niosą $\mathrm{z}$ sobą sabaty oraz uczestniczące $\mathrm{w}$ nich czarownice, ma potencjał uniwersalizujący, bowiem to właśnie obraz oblubienicy szatana został ukształtowany jako uosobienie odpowiedzialności za całe zło. Dlatego też procesy o czary stanowiły swego rodzaju socjotechniczną rozgrywkę, w której obowiązywały wyraziście określone reguły, a także zespół stałych ról i wzorów postępowania przypisywanych poszczególnym jej uczestnikom $^{66}$.

\section{Bibliografia}

ADAMCZYK J.: Czary i magia w praktyce sądów kościelnych na ziemiach polskich w późnym średniowieczu. W: Karolinscy pokutnicy i polskie średniowieczne czarownice. Konfrontacja doktryny chrześcijańskiej z życiem społecznym czarownic. Red. M. KorczewsKa. Warszawa 2007, s. 91-252.

Adamowski J.: Czas i częstotliwość łysogórskich sabatów czarownic. „Annales Universitatis Mariae Curie-Skłodowska. Sectio FF: Philologiae” 1996-1997, t. $14-15$, s. $399-409$.

Adamowski J.: Łysa Góra [hasło]. W: Słownik stereotypów i symboli ludowych. T. 1: Kosmos. Cz. 2. Ziemia, woda, podziemie. Red. J. Bartmiński, S. Niebrzegowska. Lublin 1999, s. 121-122.

Bendowska M., Żebrowski R., Borzymińska Z.: Szabat [hasło]. W: Polski słownik judaistyczny. Delet, https://delet.jhi.pl/pl/psj?articleId=15847 [data dostępu: 2.12.2020].

Boesch E.: The myth of lurking chaos. W: Between culture and biology: Perspectives on ontogenetic development. Eds. H. Keller, H. Poortinga, A. ScholMERICH. Cambridge 2002, s. 116-135.

65 Ibidem, s. 117.

66 Por. M. Komar: Czarownice i inni. Kraków 1990, s. 53. 
Boноmolec J.: Diabeł w swej postaci z okazji pytania „Jeśli sa upiory” ukazany. Warszawa 1772.

BRACHA K.: Średniowieczna metryka wizerunku świętokrzyskiej czarownicy. W: Czary, alchemia, opętanie w kulturze na przestrzeni dziejów. Studia przypadków. Red. J. Pietrzak-Thébaut, Ł. Сybulski. Warszawa 2015, s. 119-136.

Buchнамmer E.R.: Maly leksykon przesadów. O czarnym kocie, trzynastce i wampirach. Krótki kurs zabobonu, magii i hermetyki. Przeł. M. STruczyŃSKI. Warszawa 1994.

BudzanowsKa-Weglenda D.: Czarna magia antyczna i okrutne czarownice $w$ Epodzie V Horacego. W: Czary, alchemia, opętanie $w$ kulturze na przestrzeni dziejów. Studia przypadków. Red. J. Pietrzak-Thébaut, Ł. Cybulski. Warszawa 2015, s. 70-81.

Bylina S.: Kościół a kultura ludowa w Polsce późnego średniowiecza. W: Literatura i kultura późnego średniowiecza w Polsce. Red. T. Michaєówski. Warszawa 1993, s. 197-215.

Bylina S.: Kultura ludowa Polski i Słowiańszczyzny średniowiecznej. Warszawa 1999.

Bylina S.: Magia, czary i kultura ludowa $w$ Polsce XV i XVI w. „Odrodzenie i Reformacja w Polsce" 1990, t. 35, s. 39-52.

Chmielowski B.: Nowe Ateny... albo Akademia wszelkiej sciencyi petna [...]. [Wybór i prac. M. LipińsKA, J. Lipiński]. Kraków 1966.

Chudzińska-Parkosadze A.: Problem monomitu jako źródła archetypu wiedźmy $w$ kulturze europejskiej. W: Czarownice. Studia z kulturowej historii fenomenu. Red. A. Anczyк, J. Doroszewska, K.M. Hess. Katowice 2017, s. 69-78.

Eliade M.: Kobieta, ziemia i płodność. W: Idem: Sacrum i profanum. O istocie religijności. Warszawa 1999, s. 35-49.

FiŁonowicz A.: Jak się pozbyć sekutnicy? O łowach czarownic w amerykańskich filmach fantastyczno-przygodowych. W: Czarownice. Studia z kulturowej historii fenomenu. Red. A. Anczyк, J. Doroszewska, K.M. Hess. Katowice 2017 , s. $183-192$.

Graves R.: Mity greckie. Przeł. H. Krzeczkowski. Warszawa 1992.

Ho£dA R.: Czarownice a ugarycki kult boga $z$ rogami. Popularne transformacje mitu. W: Czarownice. Studia z kulturowej historii fenomenu. Red. A. ANCZYK, J. Doroszewska, K.M. Hess. Katowice 2017, s. 166-174.

Janion M.: Projekt krytyki fantazmatycznej. W: Prace wybrane. T. 3: Zło i fantazmaty. Kraków 2001, s. 157-184.

KLISz J.: Nie-ludzka kondycja czarownic: zwiąki z natura a zjawisko dehumanizacji. „Sensus Historiae” 2015, t. 21, nr 4, s. 91-112.

Komar M.: Czarownice i inni. Kraków 1990.

Koranyi K.: Beczka czarownic. „Lud” 1928, seria 2, t. 7 (27), s. 110-111.

Korany K.: Czary i gusła przed sądami kościelnymi w Polsce w XV i pierwszej połowie XVI wieku. „Lud” 1927, seria 2, t. 6 (26), Z. 1-4, s. 1-25.

Koranyi K.: Eysa Góra. Studium z dziejów wierzeń ludowych w Polsce w XVII i XVIII wieku. „Lud” 1928, seria 2, t. 7 (27), s. 57-74.

Kowalski P.: Kultura magiczna. Omen, przesą, znaczenie. Warszawa 2007.

Levack B.P.: Polowanie na czarownice $w$ Europie wczesnonowożytnej. Przeł. E. RutKowski. Kraków 2009. 
Mikikulski K., Wijaczka J.: Historia powszechna. Wiek XVI-XVIII. Warszawa 2012.

Murray M.A.: Wiedźmi kult w Europie Zachodniej. Studium antropologiczne. Przeł. A. Kisiel. Katowice 2016.

Oestrreicher-Mollowo M.: Leksykon symboli. Red. L. Robakiewicz. Warszawa 2009.

Ogrodowska B.: Zwyczaje, obrzędy i tradycje w Polsce. Mały słownik. Warszawa 2001.

OziembŁowsкi M.: Motyw lotu czarownic w tak zwanej zbiorczej koncepcji czarownictwa europejskiego. Świadectwa średniowieczne i wczesnonowożytne. „Almanach Historyczny” 2003, t. 5, s. 49-74.

Pankalla A., Pietrzak M., Gutkowska K.: Zastosowanie analizy konotacyjnej Ernesta Boescha do interpretacji obrazu Rafaela Santi „Adam i Ewa - grzech pierworodny”. „Studia Psychologica” 2014, nr 14 (1), s. 15-26.

Pilaszek M.: Procesy o czary w Polsce $w$ wiekach XV-XVIII. Kraków 2008.

Podgórska B., Podgórski A.: Encyklopedia demonów. Diabły, diabełki, jędze, skrzaty, boginki... i wiele innych. Wrocław 2000.

Poткоwski E.: Czary i czarownice. Warszawa 1970.

Russell J.B.: Krótka historia czarownictwa. Przeł. J. Ryвsкi. Wrocław 2003.

SAMP J.: Droga na sabat. Gdańsk 1981.

Szot-RAdZISZEwsKa E.: Ludowy obraz czarownicy świętokrzyskiej w świadomości mieszkańców Kielecczyzny w świetle historycznych i współczesnych źródeł etnograficznych. W: Czary, alchemia, opętanie na przestrzeni stuleci. Studia przypadków. Red. J. Pietrzak-Thébaut, Ł. Cybulski. Warszawa 2015, s. 291-303.

Thurston R.: Polowanie na czarownice. Dzieje prześladowań czarownic w Europie i Ameryce Pótnocnej. Warszawa 2008.

ТовоєА-Feliks M.: Co czarownica w kotle warzyła? Od magii i rytuału do praktyk leczniczych wiejskich zielarek. W: Doświadczenie choroby w perspektywie badań interdyscyplinarnych. T. 6: Ciało, choroby i świadomość społeczna społeczne $i$ metafizyczne aspekty profilaktyki $i$ terapii. Red. B. PŁonkA-SYROKA, M. DĄSAL. Warszawa 2020, s. 85-104.

Tomicki R.: Religijność ludowa. W: Etnografia Polski. Przemiany kultury ludowej. T. 2. Red. M. Biernacka, M. Frankowska, W. Paprocka. Wrocław 1981.

TresidDer J.: Stownik symboli. Ilustrowany przewodnik po tradycyjnych wyobrażeniach obrazowych, znakach ikonicznych i emblematach. [Przeł. B. SтокєоSA]. Warszawa 1997, s. 155-169.

Tuwim J.: Czary i czarty polskie oraz Wypisy czarnoksięskie. Warszawa 1924.

Wijaczka J.: Magia i czary. Polowanie na czarownice i czarowników w Prusach Książęcych w czasach wczesnonowożytnych. Torun 2008.

ZDZIECHIEwicz A.: Staropolskie polowania na czarownice. Katowice 2004.

Magdalena Toboła-Feliks, etnolog, muzealnik, adiunkt w Dziale Etnologii Miasta Muzeum Historii Katowic. Absolwentka etnologii oraz socjologii komunikacji społecznej Uniwersytetu Śląskiego w Katowicach. Członek Polskiego 
Towarzystwa Ludoznawczego, Oddział Cieszyn, oraz Sekcji Stroju Ludowego działającej w ramach Polskiego Towarzystwa Ludoznawczego. Interdyscyplinarne połączenie pokrewnych fakultetów pozwala jej na wieloaspektowe spojrzenie na przestrzeń społeczno-kulturową. Swoją aktywność badawczą koncentruje na kulturze wsi polskiej, zwłaszcza w zakresie problematyki chłopskich strojów ludowych. W działalności popularyzatorskiej oraz wydawniczej temat ten podejmuje w szerokim kontekście diagnostycznym. W swojej pracy odwołuje się również do interpretacji obrzędowości i wierzeń ludowych, ze szczególnym uwzględnieniem odniesień do etnobotaniki widzianej przez pryzmat kulturowo-antropologicznej wizji czarownicy. 